\title{
Article
}

\section{Transcript Dynamics in Wounded and Inoculated Scots Pine}

\author{
Vilnis Šḳipars *(1) and Dainis Rungíis (i) \\ Genetic Resource Centre, Latvian State Forest Research Institute "Silava", 111 Rigas st., LV-2169 Salaspils, Latvia; \\ dainis.rungis@silava.lv \\ * Correspondence: vilnis.skipars@silava.lv
}

check for updates

Citation: Škipars, V.; Runǵgis, D. Transcript Dynamics in Wounded and Inoculated Scots Pine. Int. J. Mol. Sci. 2021, 22, 1505. https://doi.org/ 10.3390/ijms22041505

Academic Editor: Lam-Son Phan Tran Received: 29 December 2020

Accepted: 30 January 2021

Published: 3 February 2021

Publisher's Note: MDPI stays neutral with regard to jurisdictional claims in published maps and institutional affiliations.

Copyright: (c) 2021 by the authors. Licensee MDPI, Basel, Switzerland. This article is an open access article distributed under the terms and conditions of the Creative Commons Attribution (CC BY) license (https:// creativecommons.org/licenses/by/ $4.0 /)$.

\begin{abstract}
Comparative transcriptome analysis provides a useful tool for the exploration of plantpathogen interaction by allowing in-depth comparison of gene expression between unaffected, inoculated and wounded organisms. Here we present the results of comparative transcriptome analysis in genetically identical one-year-old Scots pine ramets after wounding and inoculation with Heterobasidion annosum. We identified 230 genes that were more than 2-fold upregulated in inoculated samples (compared to controls) and 116 downregulated genes. Comparison of inoculated samp les with wounded samples identified 32 differentially expressed genes (30 were upregulated after inoculation). Several of the genes upregulated after inoculation are involved in protection from oxidative stress, while genes involved in photosynthesis, water transport and drought stress tolerance were downregulated. An NRT3 family protein was the most upregulated transcript in response to both inoculation and wounding, while a U-box domain-containing protein gene was the most upregulated gene comparing inoculation to wounding. The observed transcriptome dynamics suggest involvement of auxin, ethylene, jasmonate, gibberellin and reactive oxygen species pathways and cell wall modification regulation in response to $H$. annosum infection. The results are compared to methyl jasmonate induced transcriptome dynamics.
\end{abstract}

Keywords: Pinus sylvestris; transcriptome; Heterobasidion annosum; plant-pathogen interaction

\section{Introduction}

Scots pine (Pinus sylvestris L.) is a forest tree species of significant ecological and economic significance in Northern Europe. Among the most destructive diseases affecting Scots pine is root rot caused by Heterobasidion annosum [1]. It is essential to understand the plant-pathogen interaction to enable the development of solutions for controlling the adverse effects of the pathogen. One of the most effective ways of investigating plant responses to stress conditions is transcriptome analysis. Studies on molecular genetic aspects of conifer resistance against Heterobasidion sp. began before massively parallel sequencing techniques became widely available [2]. Massive parallel transcriptome sequencing analysis has the potential to deepen the pool of available information about differentially regulated genes and the likely biological effects of these changes. Some interesting data have been published identifying differentially expressed genes (DEGs) in white pine blister rust (caused by the biotrophic pathogen Cronartium ribicola) resistant genotypes of Pinus monticola [3]. Candidate genes for increased resistance of Pinus radiata against Fusarium circinatum were detected using RNA-seq [4] and transcriptome-based research on the expression of pathogenesis-related genes of Pinus tecunumanii after inoculation with F. circinatum has been published recently [5]. Transcriptome analysis can be applied more widely and provide more information compared to microarray hybridization or qPCR as it, per se, does not require detailed information about the genome of the studied organism to quantitate the transcripts of genes. Previous studies on Heterobasidion-conifer interaction at a transcriptome level were performed using hybridization arrays [6] in Scots pine and massively parallel sequencing in a study investigating differences in gene expression of Norway spruce genotypes with different susceptibility to Heterobasidion spp. infection [7]. 
A study describing the differences in transcriptional responses associated with virulence and defense in the interaction between $H$. annosum and Picea abies identified several differentially expressed genes that are likely involved in disease responses [8]. Therefore, transcriptome analysis of $P$. sylvestris responses to H. annosum infection will provide new information about the interaction between P. sylvestris and H. annosum. Another strategy for discovering molecular genetic information about resistance to pathogens in conifers is the identification of quantitative trait loci (QTL) [9]. The information about single nucleotide polymorphisms (SNPs) in QTLs can also be found in transcriptome data if the QTL is transcribed. Additionally, protein analysis can be used for studies of differences in stress responses [10,11]. Researchers are also studying constitutive resistance [12] and induced resistance [13]. Transcriptome studies can be focused on phytohormone-linked genes and integrated with phytohormone profiling to reveal a combined phytohormone-focused view of plant-pathogen interactions [14]. Alternatively, the impact of phytohormones on the transcriptome can be studied [15], gaining valuable information that can be used for comparisons with other treatments, as done in this study. However, to enable a thorough interpretation of transcriptome sequencing data, a reference genome or transcriptome with detailed gene annotation information is required. In comparison to other model and crop species, conifer genome resources are less comprehensive, but several genome assemblies [16,17] and transcriptomes [18-20] are available, as well as H. annosum transcriptomic and genomic resources [21,22]. The constantly growing amount of information about conifer genes and proteins deposited in public databases also means that the data obtained in experiments investigating transcriptional responses of conifers to pathogens, especially if obtained with high throughput sequencing technologies, should be periodically reexamined.

Scots pine is the dominant species in Latvia, and the breeding program produces improved germplasm for forest renewal. However, currently, selection criteria are focused on growth and stem quality characteristics. The significance of this study lies in the high economic importance of Scots pine- $\mathrm{H}$. annosum pathosystem. Our results indicate potential candidate genes for further research, with the ultimate aim of identifying Scots pine germplasm with increased resistance to H. annosum infection. The specific aim of this study was to identify the changes in the transcriptome of Scots pine in response to inoculation with H. annosum and to clarify which of these changes are inoculation-specific. As phytohormones are important regulators of plant defense responses, the analysis and discussion were also focused on this aspect.

\section{Results}

The transcriptome sequencing resulted in $\sim 59.1$ million reads with an average length of 78 base pairs (bp). Details regarding reading count per library and mean read length are provided in Table 1.

Table 1. Read count and read length of transcriptome sequencing libraries.

\begin{tabular}{cccc}
\hline Library Name & Treatment & Reads & Mean Read Length, bp \\
\hline $26 S$ & Control & $8,403,116$ & 79 \\
$27 S$ & Control & $5,338,286$ & 73 \\
$23 S$ & Wounding & $5,679,288$ & 90 \\
$25 S^{*}$ & Wounding & $3,386,611$ & 82 \\
$29 S$ & Wounding & $9,003,982$ & 69 \\
$21 S$ & Inoculation & $9,821,725$ & 95 \\
$30 S$ & Inoculation & $7,669,090$ & 61 \\
$34 S$ & Inoculation & $9,815,442$ & 78 \\
\hline
\end{tabular}

* omitted from data analysis due to deviation principal component analysis.

Libraries obtained from control, wounded, and inoculated samples were mapped against an $H$. annosum reference transcriptome to confirm inoculation and to identify pathogen genes. The reads from control libraries produced at least one hit with 9190 of 
$13,405$ H. annosum reference transcripts ( $68.56 \%)$; for the wounded sample and inoculated sample libraries, this number is, respectively, 9225 and $11,176(\sim 68.82 \%$ and $83.37 \%)$. Filtering for false discovery rate-adjusted $\mathrm{P}$ values identified 54 transcripts "differentially expressed" between control and inoculated samples, 52 of them were "upregulated". One "downregulated" transcript was identified comparing wounded and control samples. Supplementary Table S1 contains two sheets showing the "differential expression analysis" results for inoculated and wounded samples compared to controls. These results confirm the presence of active H. annosum in the inoculated samples.

The obtained number of reads per library is sufficient for meaningful RNA seq based transcript quantification and differential expression studies [23,24]. After exclusion of the outlier library, up- and downregulated transcripts were identified (Table 2).

Table 2. Number of significantly up- or downregulated transcripts depending on treatment.

\begin{tabular}{ccc}
\hline Compared & $\begin{array}{c}\text { Number of Upregulated } \\
\text { Transcripts }\end{array}$ & $\begin{array}{c}\text { Number of Downregulated } \\
\text { Transcripts }\end{array}$ \\
\hline Inoculated vs. control & 230 & 116 \\
Wounded vs. control & 96 & 48 \\
Inoculated vs. wounded & 30 & 2 \\
\hline
\end{tabular}

Absolute fold change (Abs. F. C.) $\geq|2|$; false discovery rate (FDR) adjusted $p<0.05$.

The number of unique and common DEGs between different treatments is shown in Figure 1. All DEGs that overlap between treatments are differentially expressed in the same direction.

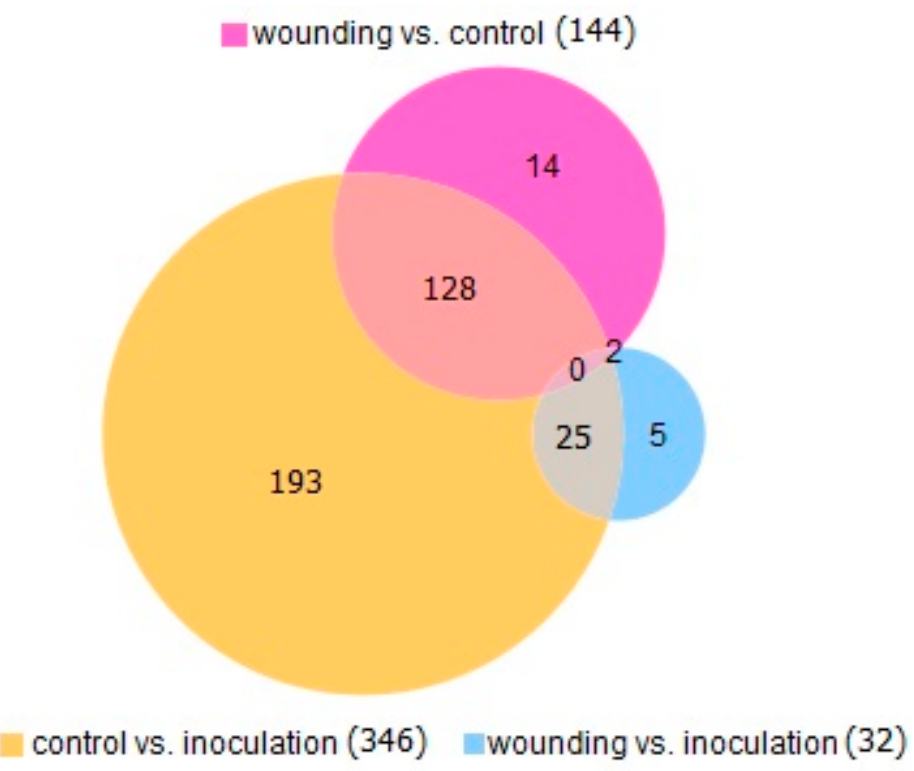

Figure 1. Number of DEGs depending on treatment.

After inoculation, a transcript representing a Casparian strip membrane protein (CASP) family member was the most upregulated. Other highly upregulated transcripts included an NRT3 family protein, two Kunitz type trypsin inhibitor/alpha-amylase/subtilisin inhibitor genes, a polyadenylate-binding protein and others. The ten most upregulated transcripts after inoculation are shown in Table 3.

A transcript encoding an expansin-like protein was the most downregulated transcript $\left(\log _{2} \mathrm{FC}=9.21\right)$. As reviewed by Cosgrove [25], expansins are involved in plant cell wall growth and stress responses (abiotic and biotic). The ten most downregulated transcripts (Table 4) include genes involved in cell wall maintenance, defense against pathogens, mitochondrial electron transport chain, water transport and water stress tolerance, cell signaling, gene expression regulation and insect resistance. 
Table 3. Eleven (10 annotated) most upregulated transcripts after inoculation (compared to control).

\begin{tabular}{|c|c|c|c|c|}
\hline Mapping Reference ID & Annotation (BLASTx) & Accession & $\begin{array}{l}\text { Log2 FC (Control vs. } \\
\text { Inoculation) }\end{array}$ & FDR $p$-Value \\
\hline comp45373_c0_seq2 & $-\mathrm{NA}-$ & mitochondrial sequence & -9.05 & $2.36 \times 10^{-8}$ \\
\hline comp52925_c0_seq1 & CASP-like protein 5A2 & P0DI70 & -6.92 & 0 \\
\hline comp36432_c0_seq1 & NRT3 family protein & AQX43117 & -6.77 & $2.08 \times 10^{-4}$ \\
\hline comp53900_c0_seq3 & $\begin{array}{c}\text { Alpha-amylase/subtilisin } \\
\text { inhibitor-like }\end{array}$ & XP_004488980 & -6.72 & $4.61 \times 10^{-8}$ \\
\hline comp53900_c0_seq2 & Kunitz-type trypsin inhibitor & OMO78033 & -6.63 & $3.85 \times 10^{-11}$ \\
\hline comp50080_c0_seq8 & $\begin{array}{c}\text { Polyadenylate-binding protein } 2 \\
\text { isoform } X 1\end{array}$ & RWR79297 & -6.33 & $1.48 \times 10^{-6}$ \\
\hline comp55480_c0_seq16 & UDP-glycosyltransferase 86A1 & XP_008779947 & -5.99 & $4.57 \times 10^{-3}$ \\
\hline comp10846_c0_seq1 & $\begin{array}{l}\text { U-box domain-containing protein } \\
\text { 6-like isoform X1 }\end{array}$ & RWR96867 & -5.79 & $6.5 \times 10^{-10}$ \\
\hline $\begin{array}{l}\text { comp50991_c0_seq1 } \\
\text { comp38130_c0_seq1 }\end{array}$ & $\begin{array}{l}\text { 12-Oxophytodienoate reductase } \\
\text { PB1 domain-containing protein }\end{array}$ & $\begin{array}{l}\text { XP_006853946 } \\
\text { GAV63268 }\end{array}$ & $\begin{array}{l}-5.71 \\
-5.71\end{array}$ & $\begin{array}{c}2.93 \times 10^{-5} \\
0\end{array}$ \\
\hline comp52813_c0_seq2 & $\begin{array}{l}\text { Phosphoenolpyruvate carboxykinase } \\
\text { (ATP) }\end{array}$ & XP_030528286 & -5.58 & $1.2 \times 10^{-2}$ \\
\hline
\end{tabular}

Table 4. Ten most downregulated transcripts after inoculation.

\begin{tabular}{lcccc}
\hline Mapping Reference ID & Annotation (BLASTx) & Accession & $\begin{array}{c}\text { Log2 FC (Control vs. } \\
\text { Inoculation) }\end{array}$ & FDR $p$-Value \\
\hline comp53647_c0_seq1 & Expansin-like protein & ADM74637 & 9.21 & $9.42 \times 10^{-3}$ \\
comp49135_c0_seq1 & Antimicrobial peptide 1 & AAL05052 & 9.19 & $1.59 \times 10^{-2}$ \\
comp50799_c0_seq2 & Cytochrome b-c1 complex subunit & XP_024197491 & 8.16 & $3.48 \times 10^{-2}$ \\
comp41900_c0_seq2 & Rieske-4, mitochondrial-like & XP_006849900 & 5.75 & $1.96 \times 10^{-3}$ \\
comp42474_c0_seq1 & Chaperone protein dnaJ 10 & XP_028756179 & 5.24 & $9.89 \times 10^{-4}$ \\
comp49517_c0_seq4 & Aquaporin TIP2-1 & PSR96031 & 5.11 & $2.8 \times 10^{-2}$ \\
comp55091_c0_seq2 & Serine/threonine-protein kinase & XP_020530211 & 5.02 & $3.37 \times 10^{-3}$ \\
comp54141_c0_seq13 & SUVR55 isoform X1 & CAD54624 & 4.82 & $7.77 \times 10^{-6}$ \\
comp54141_c0_seq10 & Dehydrin 7 protein & CAD54624 & 4.38 & $1.28 \times 10^{-2}$ \\
comp54908_c0_seq3 & Dehydrin 5 & XP_020526525 & 4.37 & $3.48 \times 10^{-2}$ \\
\hline
\end{tabular}

Four of the ten most upregulated wounding-induced transcripts (Table 5) are also among the ten most upregulated transcripts after inoculation. All genes in Table 5 are also upregulated in response to inoculation.

Table 5. Ten most upregulated transcripts after wounding.

\begin{tabular}{|c|c|c|c|c|}
\hline Mapping Reference ID & Annotation (BLASTx) & Accession & Log2 FC (Control vs. Wounding) & FDR $p$-Value \\
\hline comp36432_c0_seq1 & NRT3 family protein & AQX43117 & 6.88 & $4.17 \times 10^{-4}$ \\
\hline comp53900_c0_seq3 & Alpha-amylase/subtilisin inhibitor-like & XP_004488980 & 6.39 & $1.4 \times 10^{-6}$ \\
\hline comp53900_c0_seq2 & Kunitz-type trypsin inhibitor & OMO78033 & 5.84 & $1.11 \times 10^{-7}$ \\
\hline comp50991_c0_seq1 & 12-Oxophytodienoate reductase 3 & XP_006853946 & 5.14 & $1.39 \times 10^{-3}$ \\
\hline comp47322_c0_seq1 & 4-Coumarate-CoA ligase-like 7 & XP_021648414 & 4.72 & $3.8 \times 10^{-5}$ \\
\hline comp49557_c0_seq4 & $\begin{array}{c}\text { Lipid transfer-like protein VAS } \\
\text { Probable }\end{array}$ & XP_021646589 & 4.66 & $7.15 \times 10^{-5}$ \\
\hline comp44972_c0_seq1 & $\begin{array}{l}\text { UDP-N-acetylglucosamine-peptide } \\
\text { N-acetylglucosaminyltransferase SEC }\end{array}$ & XP_010926674 & 4.48 & $3.24 \times 10^{-2}$ \\
\hline comp54755_c0_seq16 & 2-Methyl-3-buten-2-ol synthase & ADZ45514 & 4.47 & $2.27 \times 10^{-8}$ \\
\hline comp50925_c0_seq1 & Protein flp & PFX34647 & 4.38 & $4.45 \times 10^{-2}$ \\
\hline comp39845_c0_seq1 & Class VII chitinase & QEL09553 & 4.19 & $5.55 \times 10^{-3}$ \\
\hline
\end{tabular}

Other genes highly upregulated after wounding include peroxidases, glucan endo-1,3alpha-glucosidases and enzymes for cysteine and phenolic compound metabolism.

The ten most downregulated genes after wounding are listed in Table 6. Two of the downregulated transcripts from this list (dehydrin and expansin-like protein) have closely related transcripts that are among the most downregulated after inoculation. 
Other downregulated genes include catalases, a gene encoding an auxin-repressed protein, abscisic acid and water-stress-induced protein, chloroplast-related genes, and an anthocyanidin reductase.

The ten most upregulated annotated genes, comparing inoculation to wounding, as well as the only downregulated genes in this comparison, are shown in Table 7. Four of these genes are also among the most upregulated after inoculation (Table 3). These are the genes for the U-box domain-containing protein, CASP protein, polyadenylate-binding protein and UDP-glycosyltransferase. Additionally, an uncharacterized transcript, which, according to a BLASTn search, could represent a mitochondrial transcript, is also upregulated when comparing inoculation to wounding or control conditions. All differentially expressed genes and expression levels are presented in Supplementary Table S2.

Table 6. Ten most downregulated transcripts after wounding.

\begin{tabular}{|c|c|c|c|c|}
\hline Mapping Reference ID & Annotation (BLASTx) & Accession & Log2 FC (Control vs. Wounding) & FDR $p$-Value \\
\hline comp55025_c0_seq2 & NADH dehydrogenase subunit 5 & AEB54948 & -5.79 & $2.08 \times 10^{-2}$ \\
\hline comp54020_c0_seq2 & Aspartyl protease ED3-like & XP_031372971 & -5.77 & $1.13 \times 10^{-6}$ \\
\hline comp54141_c0_seq7 & dehydrin 5 & CAD54624 & -5.38 & $1.56 \times 10^{-3}$ \\
\hline comp52309_c0_seq4 & $\begin{array}{l}\text { Serine/threonine protein phosphatase } \\
2 \mathrm{~A} \text { regulatory subunit B beta-like }\end{array}$ & XP_020276947 & -4.70 & $8.94 \times 10^{-3}$ \\
\hline comp27926_c0_seq1 & Nonspecific lipid-transfer protein 2-like & KZV55795 & -4.08 & $1.76 \times 10^{-4}$ \\
\hline comp53647_c0_seq2 & Expansin-like protein & PSS08250 & -3.83 & $2.56 \times 10^{-3}$ \\
\hline comp53589_c0_seq1 & $\begin{array}{c}\text { Cytochrome P450 monooxygenase } \\
\text { CYP736B }\end{array}$ & ACN89833 & -3.69 & $3.18 \times 10^{-2}$ \\
\hline comp55331_c0_seq2 & $\begin{array}{l}\text { Putative clathrin assembly protein } \\
\text { At2g25430 }\end{array}$ & XP_008784532 & -3.60 & $9 \times 10^{-3}$ \\
\hline comp53823_c0_seq2 & $\begin{array}{l}\text { Glyceraldehyde-3-phosphate } \\
\text { dehydrogenase 3, cytosolic }\end{array}$ & P34924 & -3.44 & $3.46 \times 10^{-3}$ \\
\hline comp54141_c0_seq5 & Dehydrin & CCG34065 & -3.24 & $5.83 \times 10^{-5}$ \\
\hline
\end{tabular}

Table 7. Eleven most upregulated (10 annotated) and two downregulated genes after inoculation, compared to wounding.

\begin{tabular}{|c|c|c|c|c|}
\hline Mapping Reference ID & Annotation (BLASTx) & Accession & $\begin{array}{l}\log 2 \text { FC (Wounding vs. } \\
\text { Inoculation) }\end{array}$ & FDR $p$-Value \\
\hline comp10846_c0_seq1 & $\begin{array}{l}\text { U-box domain-containing protein 6-like } \\
\text { isoform X1 }\end{array}$ & RWR96867 & -7.48 & $6.72 \times 10^{-5}$ \\
\hline comp45373_c0_seq2 & $-\mathrm{NA}-$ & $\begin{array}{l}\text { Mitochondrial } \\
\text { sequence }\end{array}$ & -7.14 & 0 \\
\hline comp52925_c0_seq1 & CASP-like protein 5A2 & P0DI70 & -6.72 & 0 \\
\hline comp50080_c0_seq8 & Polyadenylate-binding protein 2 isoform $\mathrm{X} 1$ & RWR79297 & -6.27 & $1.24 \times 10^{-5}$ \\
\hline comp38130_c0_seq1 & PB1 domain-containing protein & GAV63268 & -6.18 & 0 \\
\hline comp1010735_c0_seq1 & 605 ribosomal protein L13a-4-like & XP_024356575 & -5.02 & $3.18 \times 10^{-10}$ \\
\hline comp40240_c0_seq2 & Pre-mRNA-splicing factor ISY1 homolog & XP_006854550 & -4.93 & 0 \\
\hline comp52309_c0_seq4 & $\begin{array}{l}\text { Serine/threonine protein phosphatase 2A } \\
\text { regulatory subunit B beta-like }\end{array}$ & XP_020276947 & -4.65 & $1.78 \times 10^{-2}$ \\
\hline comp40935_c0_seq1 & NAC domain-containing protein 86 -like & XP_026666241 & -4.48 & $5.06 \times 10^{-3}$ \\
\hline comp55480_c0_seq16 & UDP-glycosyltransferase 86A1 & XP_008779947 & -4.10 & $6.42 \times 10^{-3}$ \\
\hline comp54163_c0_seq3 & $\begin{array}{l}\text { L-type lectin-domain-containing receptor } \\
\text { kinase S.4-like }\end{array}$ & XP_010937574 & -4.08 & $2.46 \times 10^{-10}$ \\
\hline \multicolumn{5}{|c|}{ Downregulated } \\
\hline comp55005_c0_seq1 & Paladin isoform $\mathrm{X} 2$ & XP_006841555 & 5.11 & $9.72 \times 10^{-6}$ \\
\hline comp41900_c0_seq2 & Chaperone protein dnaJ 10 & XP_006849900 & 6.28 & $1.75 \times 10^{-3}$ \\
\hline
\end{tabular}

Gene ontology (GO) data were obtained and GO term enrichment was assessed by use of Blast2GO plugin for CLC Genomics Workbench. In many cases, the transcripts produced GO descriptions of different levels of detail, which hinders apprehensible data representation. A graph representing biological processes $\mathrm{GO}$ classifications represented by all DEGs is provided in Supplementary Figure S1. 


\section{Discussion}

\subsection{Comparison of Differentially Expressed Genes Between Inoculated and Wounded Samples}

Thirty genes were differentially expressed between wounded and inoculated samples. Such genes should be important in biotic stress management thus are potential candidate genes for further research in plant defense as polymorphisms in these genes, or their regulatory regions might favorably influence biotic stress responses. GO annotations provide information indicating the role of these DEGs in transcription, mRNA processing and translation (Table 8).

Table 8. Frequency of GO descriptions (GO term level 7) for the transcripts differentially expressed between inoculation and wounding.

\begin{tabular}{cc}
\hline Biological Process & $\begin{array}{c}\text { Number of } \\
\text { Sequences }\end{array}$ \\
\hline Protein phosphorylation & 2 \\
ncRNA metabolic process & 2 \\
ncRNA processing & 2 \\
Nucleic acid-templated transcription & 1 \\
mRNA splice site selection & 1 \\
Spliceosomal conformational changes to generate catalytic conformation & 1 \\
mRNA processing & 1 \\
tRNA modification & 1 \\
rRNA processing & 1 \\
Cellular protein-containing complex assembly & 1 \\
Protein modification by small protein conjugation or removal & 1 \\
Regulation of dephosphorylation & 1 \\
Regulation of nucleic acid-templated transcription & 1 \\
Chlorophyll metabolic process & 1 \\
Regulation of phosphoprotein phosphatase activity & 1 \\
Regulation of protein dephosphorylation & 1 \\
Protein dephosphorylation & 1 \\
Spliceosomal complex assembly & 1 \\
mRNA metabolic process & 1 \\
\hline Generation of catalytic spliceosome for second transesterification step & 1 \\
Porphyrin-containing compound biosynthetic process & 1 \\
RNA splicing & 1 \\
\hline
\end{tabular}

GO information about cellular localization of the proteins encoded by these DEGs shows their involvement in ribosome biogenesis, spliceosomal complex, ER membrane and plasmatic membrane (Supplementary Figure S2). Several of them are involved in signaling, cell cycle regulation, cell wall maintenance and protein homeostasis. A summary of the functions of these genes is provided in Supplementary Table S3.

\subsection{Inoculation-Specific Changes in Gene Expression Compared to Control}

Another group of genes, those differentially expressed in response to inoculation, but not wounding, is intrinsically interesting for plant defense studies as genes in this group represent an inoculation-specific defense response and structural variation, and differential expression of these genes might be of interest for further research of plant resistance mechanisms. In this group are 218 genes (143 upregulated and 75 downregulated genes). Tables 3 and 4 show information about the most up- and downregulated genes, respectively, but these tables include the section of the differential transcriptome, which overlaps with the wounding treatment. Fisher's exact test (performed in the Blast2GO plugin for CLC genomic workbench using $p<0.05$ as the threshold) analysis of GO frequencies revealed the most prominent differences in biological processes (Figure 2) and molecular functions (Figure 3) that the DEGs of this segment of the differential transcriptome are involved in. 


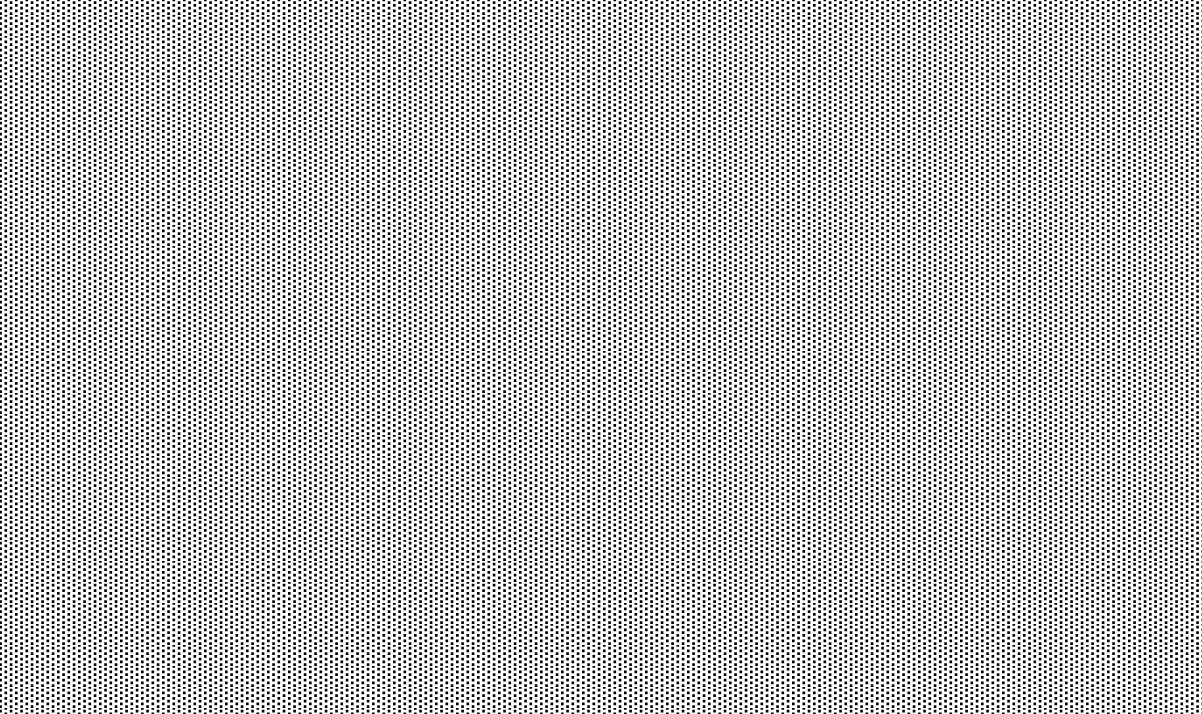

Figure 2. Biological processes with most up- and downregulated differentially expressed genes (DEGs) (inoculation vs. control) determined by Fisher's exact test using $p<0.05$ as the threshold.



Figure 3. Molecular functions with most up- and downregulated DEGs (inoculation vs. control) determined by Fisher's exact test using $p<0.05$ as the threshold. 
In addition, to GO analysis (which often identifies different levels of detail for different DEGs, and thus can be inconvenient for result representation and interpretation), BLASTx result description analysis, simplifying the assigned gene descriptions and calculating their frequencies, can be useful (Table 9).

Table 9. Comparison of most frequent simplified DEG descriptions between inoculation-specific up- and downregulated transcriptome segments (total number of upregulated DEGs $=143$, downregulated DEGs $=75$ ).

\begin{tabular}{|c|c|c|c|}
\hline Description of Upregulated DEGs & Quantity & Description of Downregulated DEGs & Quantity \\
\hline Receptor & 9 & Receptor & 5 \\
\hline WRKY transcription factor & 5 & Aquaporin & 4 \\
\hline Peroxidase & 4 & Protease/proteinase & 4 \\
\hline Protease/proteinase & 3 & $\begin{array}{l}\text { Embryo- (late embryogenesis-) } \\
\text { abundant protein }\end{array}$ & 3 \\
\hline Methyltransferase & 3 & ABA-induced protein & 2 \\
\hline U-box domain-containing protein & 3 & Cytochrome & 2 \\
\hline UDP-glycosyltransferase & 3 & Dehydrin & 2 \\
\hline Benzyl alcohol O-benzoyltransferase & 2 & EDS1L & 2 \\
\hline Chitinase & 2 & NRT1/ PTR family protein & 2 \\
\hline Cinnamyl-alcohol dehydrogenase & $2 \mathrm{~T}$ & thaumatin-like protein & 2 \\
\hline Cytochrome P450 & 2 & & \\
\hline E3 ubiquitin-protein ligase & 2 & & \\
\hline Glutathione peroxidase & 2 & & \\
\hline Indole-3-acetate O-methyltransferase & 2 & & \\
\hline PAR1 transcription factor & 2 & & \\
\hline Pentatricopeptide repeat-containing protein & 2 & & \\
\hline Ribosomal protein & 2 & & \\
\hline Sugar transport protein & 2 & & \\
\hline Tau class glutathione S-transferase & 2 & & \\
\hline Thioredoxin reductase & 2 & & \\
\hline tRNA modifying enzyme & 2 & & \\
\hline
\end{tabular}

Four downregulated DEG descriptions include plant hormones (abscisic acid twice, auxin and gibberellin —once each). Upregulated DEG descriptions included auxin, indole3-acetate O-methyltransferase (an enzyme converting IAA (auxin) to methyl-IAA with different biological activity [26]) (twice), 1-aminocyclopropane-1-carboxylate oxidase 5 (an enzyme involved in ethylene synthesis [27]), 12-oxophytodienoate reductase 11 (involved in methyl jasmonate (MeJa) synthesis and other signaling pathways [28]), and DMR6-like oxygenase 1, alternative name salicylate 3-hydroxylase DLO1 (converts salicylic acid (SA) to 2,3-dihydroxybenzoic acid thus negatively regulates SA content [29]). In addition to plant hormones, upregulated DEG descriptions also include glutamate synthase, which synthesizes glutamate (which, as reviewed by Qiu et al. [30], is involved in plant stress response signaling) and genes involved in $\mathrm{Ca}^{2+}$ (role as secondary messenger) homeostasis (calcium-binding protein, calcium-transporting ATPase 1).

The results presented in Figures 2 and 3 and Table 9 show that inoculation-specific changes upregulate metabolic processes, oxidation-reduction processes, response to oxidative stress, and downregulate water transport. Both up- and downregulation of several receptor genes (receptor-like protein kinases) were detected, as well as upregulation of several genes encoding WRKY transcription factors and other genes relevant for translation. Aquaporin and dehydrin genes were downregulated, indicating that dehydration of the affected region could be a host defense strategy.

\subsection{Genes Induced by Inoculation and Wounding}

A total of 128 coregulated genes ( 87 upregulated and 41 downregulated) were detected comparing inoculation and wounding responses vs. control. Fisher's exact test analysis of GO frequencies identified the most prominent differences between the up- and down- 
regulated segments of this part of the differential transcriptome related to biological processes and molecular functions (Figures 4 and 5).

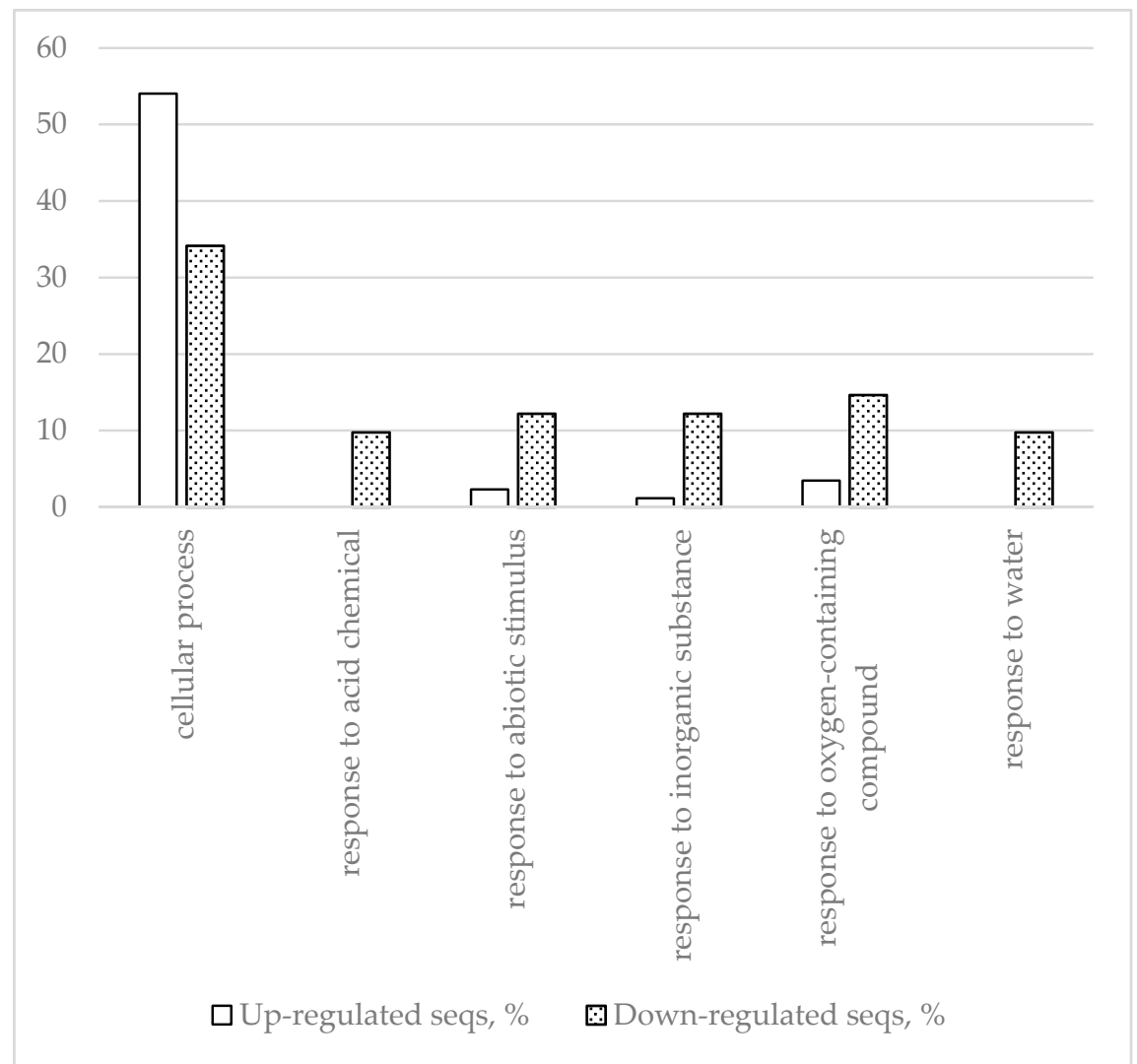

Figure 4. Biological processes with most up- and downregulated DEGs (inoculation/wounding vs. control) determined by Fisher's exact test using $p<0.05$ as the threshold.

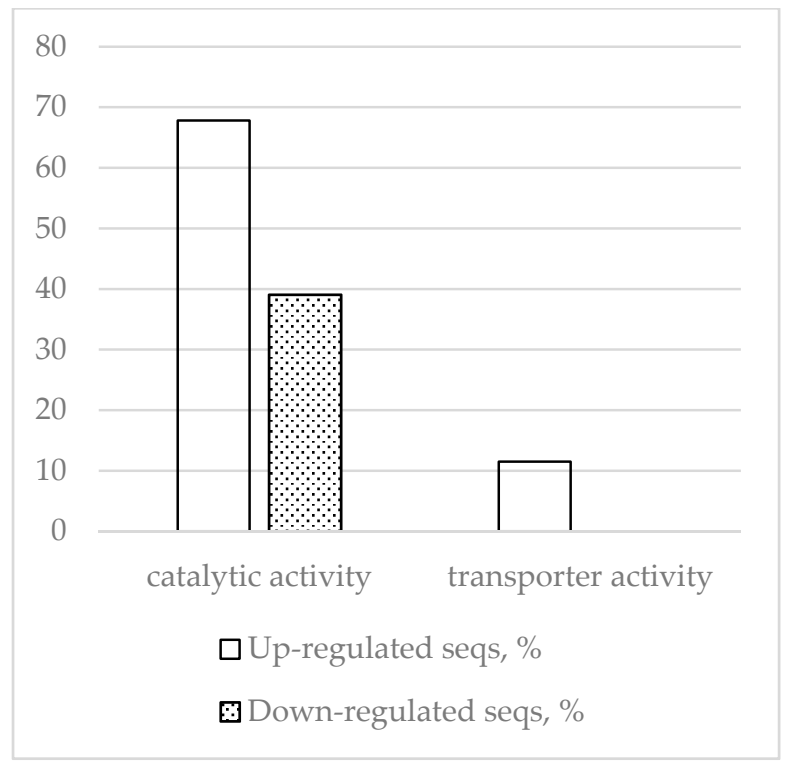

Figure 5. Molecular functions with most up- and downregulated DEGs (inoculation/wounding vs. control) determined by Fisher's exact test using $p<0.05$ as the threshold.

Table 10 provides information about the most common DEG descriptions. 
Table 10. Comparison of most frequent simplified DEG descriptions between the up- and downregulated parts of the overlapping inoculation and wounding induced response (total number of upregulated DEGs $=87$, downregulated DEGs $=41$ ).

\begin{tabular}{cccc}
\hline Description of Upregulated DEGs & Quantity & Description of Downregulated DEGs & Quantity \\
\hline Glucosidase & 6 & Dehydrin & 4 \\
Beta-fructofuranosidase & 3 & Protease/peptidase & 4 \\
Chitinase & 3 & Peroxidase/catalase & 3 \\
Peroxidase & 3 & Chlorophyll a/b binding protein & 2 \\
12-Oxophytodienoate reductase & 2 & receptor & 2 \\
Ammonium transporter & 2 & Water-stress-inducible & 2 \\
E3 Ubiquitin-protein ligase & 2 & & \\
Linoleate lipoxygenase & 2 & & \\
Lysine histidine transporter & 2 & & \\
Protease/peptidase & 2 & & \\
Reticuline oxidase & 2 & & \\
Stilbene synthase & 2 & & \\
TIFY protein & 2 & & \\
UDP-glycosyltransferase & 2 & & \\
\hline
\end{tabular}

The results indicate that in response to both inoculation and wounding, glucosidase genes and $\beta$-fructofuranosidase genes are upregulated, but dehydrin genes and protease/peptidase genes are downregulated. Figure 5 shows that, in contrast to inoculationspecific responses, the universal response to wounding and inoculation intensifies transporter activity. This concurs with data from Table 10 showing descriptions of "ammonium transporter" and "lysine histidine transporter" in the upregulated DEGs description list. Figure 4 shows that, compared to the inoculation-specific response, the universal response is more focused on downregulation not of genes involved in water transport, but of genes involved in "response to water," which concurs with the "dehydrin" and "waterstress-inducible" descriptions on the downregulated DEG description list. Comparison of Tables 9 and 10 shows that WRKY transcription factors and receptors are absent from the list of upregulated genes in Table 10.

Four upregulated DEG descriptions mention plant hormones (auxin twice, gibberellin and ethylene-once each). In addition, enzymes involved in the biosynthesis of MeJa (12oxophytodienoate reductase and 4-coumarate-CoA ligase-like protein 7 [31]) are present in the upregulated list. Bifunctional L-3-cyanoalanine synthase/cysteine synthase, which synthesizes cysteine [32], a molecule with considerable importance in signaling and plant defense [33], is also upregulated. Hence, it is the TIFY 10B protein, which is a repressor of jasmonate responses [34]. The upregulation of genes involved in the biosynthesis of MeJa and genes for proteins repressing jasmonate responses suggests tight control of the MeJa signaling pathway.

Downregulated DEG descriptions mention auxin three times and ABA twice. One of the downregulated genes (glutamate decarboxylase gene) is responsible for the production of $\gamma$-aminobutyric acid (GABA) [35], which influences plant defense reactions in several ways [36].

Some gene descriptions occur in both up- and downregulated gene lists. Such examples include peroxidases, which, besides their role in the removal of hydrogen peroxide, are involved in the catabolism of auxin [37] and phenylalanine ammonia-lyase (PAL), which is not only involved in lignin production but also, to some degree, in the production of salicylic acid precursors [38].

\subsection{Wounding-Specific Responses}

Fourteen transcripts were differentially expressed specifically after wounding. Eight of these are upregulated, and six are downregulated compared to controls. Gene annotation descriptions of the upregulated transcripts (provided in order of decreasing induction) include a protein called enhanced disease resistance 2, a ubiquitin domaincontaining protein, a nucleotide-diphospho-sugar transferase, an H-type thioredoxin, a receptor (serine/threonine-protein kinase), a cysteine-rich repeat secretory protein, a NAC 
domain-containing protein, one transcript was unannotated. Downregulated transcripts included (in order of increasing downregulation): ubiquitin domain-containing protein, dehydrin 7, glyceraldehyde-3-phosphate dehydrogenase, clathrin assembly protein, cytochrome P450 monooxygenase, NADH dehydrogenase subunit 5 . The suppression of gene expression was more pronounced than induction - the absolute fold change for the most suppressed gene, NADH dehydrogenase subunit 5, was -55, while the most-induced gene, enhanced disease resistance 2 , showed a fold change of 8.6. This short list shows that there are two differently regulated members of ubiquitin domain-containing protein in this segment of the differential transcriptome. The downregulated genes are related to water stress tolerance and general cell functions, while the upregulated genes can be linked to defense responses.

\subsection{Transcription Factors and Signaling Pathways}

\subsubsection{Transcription Factors}

Several WRKY TFs are upregulated in response to inoculation, and no WRKY TF transcripts were downregulated. The upregulated WRKY TFs have been documented to be involved in plant defense responses. Besides the WRKY TFs, a VQ motif-containing protein transcript is induced. This is reported to interact with WRKY TFs, possibly influencing resistance. Other upregulated TFs include an ET-responsive TF (transcription activator), a PAR1 protein gene (involved in growth regulation) and others.

The downregulated TF includes zinc finger $\mathrm{CCCH}$ domain-containing protein 20 (reported to respond to oxidative stress), a NAC domain-containing protein (involved in auto-degradative processes in sieve element formation) and high mobility group B protein 1 (involved in stress tolerance and plant growth). A considerable proportion of differentially regulated TFs are inoculation specific (not differentially regulated in response to wounding).

\subsubsection{E3 Protein Ligase Complex}

A notable difference between control and inoculated samples is the upregulation of several E3 protein ligase complex transcripts; no such transcripts are downregulated. E3 protein ligases ubiquitinate proteins, thus marking them for degradation. At the same time, several genes encoding proteins involved in the regulation of transcription and translation are upregulated after inoculation, suggesting a targeted attempt by the host organism to achieve homeostasis of specific proteins or to degrade some proteins to provide building blocks for the synthesis of proteins involved in defense mechanisms. Some of these genes identified in this study represent an inoculation-specific response.

\subsubsection{Auxin}

Several up- and downregulated genes indicate regulation of auxin (IAA) levels. An auxin transporter for auxin influx is upregulated (inoculation-specifically) in addition to transcripts encoding indole-3-acetate O-methyltransferases, which convert IAA to biologically inactive IAA methyl ester (MeIAA). A methylesterase 17 analog involved in the reverse process-synthesis of IAA from MeIAA is inoculation-specifically downregulated. Several other genes involved in auxin metabolism and homeostasis regulation as well as in the regulation of auxin-responsive gene expression are differentially expressed, suggesting a change in intracellular auxin level as a response to inoculation, part of the response being inoculation-specific. The mentioned methylesterase is also involved in the metabolism of jasmonic acid (JA) and SA.

\subsubsection{Jasmonic Acid}

Expression of genes influencing jasmonic acid metabolism and the regulation of jasmonate-responsive genes is mostly similar for inoculation and wounding treatments. Transcription of TIFY 9 and TIFY 10 genes is upregulated. They are reported to repress jasmonate responses. An IAA-amino acid hydrolase, involved in JA metabolism, is also 
upregulated, as are two 12-oxophytodienoate reductases, also involved in biosynthesis of JA. A JA responsive leucoanthocyanidin synthase is downregulated. Overall, the number of DEGs related/responsive to JA are lower than for auxin and ABA.

\subsubsection{Gibberellin}

Similar to JA regulation, gene expression of gibberellin metabolism genes and gibberellin responsive genes do not show a strong inoculation specific pattern. The gibberellin $2-\beta$-dioxygenase gene transcription is induced after inoculation. This enzyme oxidizes active gibberellin into an inactive form and is involved in homeostasis of gibberellin. Oxoglutarate/iron-dependent dioxygenase, which, according to the InterPro database, could be involved in synthesis of gibberellin, is slightly upregulated. Transcription of a gibberellin regulated protein is downregulated. These data could indicate a decrease of gibberellin influence after wounding/inoculation.

\subsubsection{GABA}

Synthesis of GABA may be inhibited, as the glutamate decarboxylase gene is downregulated in response to inoculation and wounding. A recent review of GABA signaling is provided by Fromm [39]. GABA metabolism is linked with ROS levels [40], and glutamate decarboxylase is regulated by calmodulin [41]. Another calmodulin-binding protein, the transcription of the respective gene of which is slightly upregulated after inoculation (but not wounding), is a calcium-transporting ATPase 1 . As calmodulin interacts with $\mathrm{Ca}^{2+}$ [42], this establishes a link between GABA signaling and $\mathrm{Ca}^{2+}$ signaling. One of the inoculationspecifically upregulated genes encodes a probable calcium-binding protein (annotated as CML-13, member of calmodulins), which would make a stronger case for GABA-calcium signaling interaction, yet this annotation needs to be confirmed due to a lack of detailed information about this protein.

\subsubsection{ABA}

A larger number of ABA-responsive/signaling related genes are differentially regulated, some of them in an inoculation-specific manner. Ten genes are upregulated (two more than 4-fold), and six are downregulated (five more than 4 -fold). This is more than for any other single phytohormone related genes (multiphytohormone-responsive genes excluded). The most upregulated transcript (not inoculation specific) is most similar to chloroplastic magnesium-chelatase subunit, a positive regulator of ABA signaling. The rest of the upregulated genes involving $\mathrm{ABA}$ are described to be ABA-responsive. The exception is a transcript for a U-box containing protein, which possibly downregulates ABA biosynthesis.

Except for a PR10 protein, the downregulated ABA-responsive protein genes represent either ABA and water stress-induced proteins or embryo-abundant proteins, response to water stress (or involvement in damage prevention from water stress) being a common feature in addition to ABA-responsiveness. As transcription of aquaporin genes is specifically downregulated after inoculation, the downregulation of these genes may be a consequence of this. The downregulation of dehydrins (mixed inoculation-specificity of downregulation), which also protects from water stress-induced damage, is clearly pronounced in the inoculated samples.

\subsubsection{Ethylene and Salicylic Acid}

Expression of a gene for 1-aminocyclopropane-1-carboxylate oxidase, which is involved in ethylene biosynthesis, is slightly induced specifically in response to inoculation. A gene encoding a DMR6-like oxygenase, which converts SA to 2,3-dihydroxy benzoic acid, is upregulated in response to inoculation suggesting downregulation of SA signaling. 


\subsubsection{Genes Associated with Multiple Phytohormones}

A number of genes involved in the metabolism of, or response to, more than one phytohormone are differentially regulated. Only the methylesterase mentioned in context with auxin metabolism shows an expression fold change (absolute) exceeding four. The HSPRO2-like protein gene is suggested to be downregulated in response to JA and ET [43]; however, in this study, it was upregulated. However, strictosidine synthase is reported to be downregulated by auxin [44] and induced by jasmonate [45], and it was upregulated in this study. This may be the effect of fungal elicitors [44].

Two of the slightly suppressed genes in this group are functionally linked. These are lipase-like PAD4 and EDS1L-like protein genes. PAD4 probably leads to SA accumulation and, together with EDS1, seems to repress the ET/JA defense pathway. EDS1L and PAD4 are especially important in early defense responses $[46,47]$. The other downregulated genes are a chalcone synthase (responsive to auxin and JA), phospholipase D alpha (involved in wound induction of JA- and ABA-induced stomatal closure) and phenylalanine ammonialyase (in addition to lignin biosynthesis, is also involved in SA catabolism).

The expression of the PAD4 and EDS1L genes, as well as a chalcone synthase gene and one of the transcripts representing phospholipase D alpha, are suppressed while HSPRO2 is induced in an inoculation-specific manner.

\subsubsection{Calcium}

$\mathrm{Ca}^{2+}$ ions are important in the regulation of cellular processes. A gene encoding a probable Ca-binding protein, CML13, is upregulated. A glutamate receptor and Catransporting ATPase, both involved in Ca homeostasis, are also upregulated. All three genes are upregulated in an inoculation-specific manner.

\subsubsection{Water Transport and Drought Stress}

Water transport proteins (mostly aquaporins) are downregulated in response to inoculation. Drought damage prevention/water stress-responsive proteins are downregulated either specifically in response to inoculation or also downregulated in response to wounding, thus serving as another example of distinct regulation patterns for different genes from the dehydrin family. Most of the dehydrins and water stress-induced proteins are downregulated in response to wounding as well, but the most downregulated dehydrin and ABA-water-stress-induced protein gene analogs are the ones that represent an inoculation specific response.

\subsubsection{Reactive Oxygen Species Balance}

Expression of 25 oxidative stress and ROS homeostasis-related genes are induced in response to inoculation, 17 of them with abs. FC $>4$ while ten such genes are downregulated, of which six with abs. FC $>4$. This is an indication of the significant role of ROS homeostasis in host defense responses in this study. Involvement of ROS in plant defense both directly and indirectly through signaling cascades and involvement in cell wall maintenance is well-established [48]. Eleven upregulated genes and only three downregulated genes represent an inoculation-specific response. Furthermore, the three most upregulated genes showed inoculation-specific regulation.

\subsubsection{Proteases and Proteinase Inhibitors}

More proteases are downregulated than upregulated (nine vs. six), and more proteinase inhibitors are upregulated than downregulated (four vs. one). Proteinase inhibitors could represent a wounding-related defense response against herbivores. The up- and downregulated proteinases/peptidases represent the same groups of enzymes, probably representing a more detailed regulation of specific protein levels or tissue-specific regulation, which were not addressed in this study. The proteinase inhibitors are not regulated in an inoculation-specific manner, while some proteinase/peptidase genes show inoculation-specific regulation, mostly suppression. 


\subsubsection{Other Genes}

Genes coding proteins involved in detoxification, signaling, photosynthesis, synthesis of organic compounds, including compounds with antifungal activity, lignin biosynthesis, nitrate assimilation, transport of sugars and proteins directly involved in defense against fungal pathogens (chitinase, glucan endo $1,3-\alpha$ glucosidases) and others are upregulated. Stilbene synthase genes and glucan endo $1,3-\alpha$ glucosidase genes and chitinase genes are upregulated after both inoculation and wounding, but a laccase (associated with lignin degradation and detoxification of lignin-derived products, a RING-H2 finger protein (associated with early steps of defense signaling), a galacturonosyltransferase protein (involved in pectin biosynthesis) and other genes show inoculation-specific upregulation.

The inoculation-specific downregulated genes include genes for proteins directly involved in antimicrobial defense (antimicrobial peptide 1 and thaumatin-like proteins (a.k.a., PR-5 proteins)). These genes are typically members of larger gene families with different temporal, spatial and pathogen-type-specific expression patterns, so this is not unexpected.

Several of the downregulated genes are involved in photosynthesis; many are annotated as genes for receptors with protein kinase activity.

Other downregulated genes are annotated as expansin-like protein, xyloglucan endotransglucosylase/hydrolase and pectin methyltransferase genes. These are involved in cell wall maintenance, permeability regulation and cell-to-cell adhesion. An expansin-like protein gene is the most suppressed gene. If the downregulation of this gene results in the decrease of cell wall water permeability, it could be functionally consistent with the downregulation of aquaporins and suppression of drought-protective proteins. Dehydration and changes in ROS levels in response to infection are common observations, and transport of $\mathrm{H}_{2} \mathrm{O}_{2}$ by aquaporins might indicate an additional function of these proteins in plant defenses, as discussed in a review by Afzal et al. [49]. These authors also explain the reasons for difficulties in the interpretation of these results-a differential expression of very similar genes within and between species.

\subsection{Comparison to MeJa Treatment}

Comparison of the data in this paper with the data from Kānberga-Silina et al. [50] (reanalyzed using CLC Genomics Workbench and Blast2GO plugin), revealed that the number of DEGs differs (Table 11) (same logFC threshold as in Kānberga-Siliṇa et al. ( $\geq|2|$ ) is used for both NGS data sets).

Table 11. Comparison of transcriptional responses of two-year-old MeJa-treated Scots pine trees to and one-year-old wounded or inoculated (with H. annosum) Scots pine trees.

\begin{tabular}{cccc}
\hline & MeJa Treatment & Wounding & Inoculation \\
\hline Upregulated & 98 & 65 & 164 \\
Downregulated & 21 & 26 & 61 \\
Total & 119 & 91 & 225 \\
\hline
\end{tabular}

Of the 119 differentially regulated genes in response to methyl jasmonate treatment, only a few were common with responses to inoculation or wounding. Expression of eight MeJa-induced and three MeJa-suppressed genes was also differentially regulated in the inoculation/wounding experiment. Comparison of regulation of these genes in response to different treatments is presented in Table 12.

The low number of overlapping DEGs between the MeJa treatment and the inoculation experiment suggests that the MeJa signaling pathway is not the major signaling pathway in defense response to inoculation with Heterobasidion in Scots pine, in contrast to the case in Norway spruce [51]. However, the age of plant materials utilized in this experiment differs to that of Arenrup et al. [51], as well as experimental procedures of treatments.

For a larger scale comparison of the upregulated parts of transcriptomes obtained after MeJa treatment or inoculation, simplified Blast2GO annotation frequency analysis 
was performed (Table 13) showing increased frequency for chalcone synthase clavaminate synthase, chitinase and benzyl alcohol O-benzoyltransferase in the annotations for the Meja treatment. The annotations of the differential transcriptome from inoculated samples show increased frequency of peroxidases, different receptors, WRKY transcription factors and proteases/peptidases.

Table 12. Regulation of the overlapping DEGs of the MeJa and inoculation/wounding experiments.

\begin{tabular}{|c|c|c|c|c|}
\hline Reference Transcript ID & Gene Description (Blast2GO Generated) & MeJa & I & $\mathbf{W}$ \\
\hline comp51296_c0_seq1 & Glucan endo-1,3-alpha-glucosidase agn1 & + & + & + \\
\hline comp54755_c0_seq16 & 2-Methyl-3-buten-2-ol synthase & + & + & + \\
\hline comp55507_c0_seq1 & peroxidase 12 & + & + & NS \\
\hline comp55437_c0_seq1 & Alpha carbonic anhydrase 7-like & + & + & NS \\
\hline comp36780_c0_seq1 & protein TIFY 10B & + & NS & + \\
\hline comp49135_c0_seq1 & Antimicrobial peptide 1 & + & - & NS \\
\hline comp50836_c0_seq3 & Abscisic acid and water-stress-induced protein & + & - & NS \\
\hline comp53758_c0_seq2 & Leucoanthocyanidin dioxygenase-like & + & - & NS \\
\hline comp52946_c0_seq3 & Embryo-abundant protein & - & - & NS \\
\hline comp55009_c0_seq7 & BURP domain protein RD22-like isoform X1 & - & - & NS \\
\hline comp54020_c0_seq5 & Aspartyl protease ED3 & - & - & NS \\
\hline
\end{tabular}

MeJa — treatment with methyl jasmonate, I-inoculation, W—wounding, plus sign—upregulation, minus sign—downregulation of gene expression, NS-change not statistically significant (FDR $p$-value $\geq 0.05$ or $\log F C<|2|$ ).

Table 13. Comparison of most frequent simplified Blast2GO annotations of upregulated DEGs between the inoculation and MeJa treatment experiments (total number of upregulated DEGs after inoculation $=164$, upregulated DEGs after MeJa treatment $=98$ ).

\begin{tabular}{cccc}
\hline Inoculation & & MeJa Treatment \\
\hline Simplified Description & Count & Simplified Description & Count \\
\hline Peroxidase & 7 & Chalcone synthase & Clavaminate synthase \\
Receptor & 7 & chitinase & 4 \\
WRKY transcription factor & 6 & Benzyl alcohol O-benzoyltansferase & 3 \\
Protease/peptidase & 5 & 2-Methyl-3-buten-2-ol synthase & ABC transporter \\
UDP-glycosyltransferase & 5 & Alpha carbonic anhydrase & 2 \\
Chitinase & 4 & Leucoanthocyanidin dioxygenase & 2 \\
Glucan endo-1,3-glucosidase & 4 & PDR1 & 2 \\
12-Oxophytodienoate reductase & 3 & Phenylalanine ammonia-lyase \\
Beta-fructofuranosidase & 3 & Phospho-2-dehydro-3-deoxyheptonate aldolase \\
E3 ubiquitin-protein ligase & 3 & 1-Deoxy-D-xylulose-5-phosphate synthase \\
Proteinase inhibitor & 2 & Methyltransferase & 2 \\
Ammonium transporter & 2 & Proteinase inhibitor \\
Benzyl alcohol O-benzoyltransferase & 2 & Inactive purple acid phosphatase \\
Indole-3-acetate O-methyltransferase & 2 & Lipoxygenase \\
Linoleate lipoxygenase & 2 & Glutathione S-transferase \\
Lipid transfer protein & 2 & \\
Methyltransferase & 2 & \\
Reticuline oxidase & 2 & \\
Stilbene synthase & 2 & \\
Thioredoxin reductase & 2 & \\
VQ motif-containing protein & 2 & \\
U-box domain-containing protein & & \\
\hline
\end{tabular}

The comparison suggests that a signaling pathway influencing WRKY transcription factors could be significant in defense response to necrotrophic fungal infection. However, there are some similarities between inoculation and MeJa treatment responsesoxophytodienoate reductase is involved in MeJa metabolism [28], and 2-methyl-3-buten2-ol synthase is involved in terpene metabolism [52], as is stilbene synthase. Linoleate lipoxygenase is responsive to MeJa [53], as are several WRKY transcription factors [54]. In addition, the samples analyzed in this study may represent an early stage in the methyl jasmonate pathway in the inoculated samples, in comparison to the MeJa treatment study, which directly investigated the later stage of this pathway (after MeJa treatment). 
The few observed overlapping genes in the DEG list and differences in the most upregulated genes suggests a significantly more complex signaling network than a methyl jasmonate centered pathway in the reaction of Scots pine to inoculation with $H$. annosum. Based on the obtained results, water transport prevention and prevention of dehydrinbased mitigation of draught stress is a possible strategy of Scots pine defense against infection. The transcriptome analysis also shows that many genes are involved in both ROS and protein homeostasis. However, annotation of Scots pine genes is not complete, and meaningful information about the possible functions of many differentially expressed transcripts was not available, therefore the role of several transcripts involved in these defense responses needs to be further investigated. In addition, differential gene expression profiles should be investigated in a range of Scots pine germplasm, to investigate the transcriptomic differences between individuals and their relation to differential resistance to pathogens.

\section{Materials and Methods}

One-year-old P. sylvestris ramets obtained by grafting of twigs of the individual Ja2-III4 were used for the experiment. They were inoculated or wounded on September 5, 2016 and collected one day after treatment. Analysis of samples collected at similar time points after inoculation have been previously reported in other Scots pine- $H$. annosum studies [6,55]. Agar containing H. annosum mycelia (isolate V Str 28) was used for inoculation. Before inoculation, the bark was removed with a scalpel after the removal of needles at the treatment area. The media containing the mycelia was applied, with the upper surface of media facing the wounded area. For wounded samples, sterile agar media was applied instead of media containing H. annosum. For control samples only the needles were removed from the same height of the sapling at which the treatment of the other samples was done. The trees were kept outside before and during the experiment. Air temperature at the day of inoculation was $+17^{\circ} \mathrm{C}$ and $+19^{\circ} \mathrm{C}$ at the day of sample collection. For sample collection, an $\sim 3 \mathrm{~cm}$ long fragment of the tree stem containing the area of inoculation/wounding and $\sim 1 \mathrm{~cm}$ of the surrounding area in both directions was excised and placed into a two $\mathrm{mL}$ test tube, which was then frozen in liquid nitrogen and stored at $-80^{\circ} \mathrm{C}$ until RNA extraction.

RNA was extracted from a cross-section of the area of the stem where the manipulations had been performed. The RNA was extracted by use of Genomic DNA purification kit (\#K0512, Thermo Fisher Scientific, Vilnius, Lithuania) and a modified protocol for RNA extraction [56]. The integrity of the obtained RNA samples was assessed on the 2100 Bioanalyzer (Agilent, Santa Clara, CA, USA) using an RNA nano chip following the manufacturer's instructions. RNA integrity (RIN) values of the samples used in downstream analysis exceeded 7.

Ribosomal RNA was removed using the RiboMinus ${ }^{\mathrm{TM}}$ Plant kit for RNA-Seq, and the transcriptome libraries were prepared using the ion total RNA-Seq Kit v2 (both kits from Thermo Fisher Scientific, Waltham, MA, USA). Further sequencing procedures, including emulsion PCR and ion torrent sequencing on the Ion Proton instrument (Thermo Fisher Scientific, Waltham, MA, USA) using the ion PI chip, were performed at the Latvian Biomedical Research and Study Center.

For the data analysis, CLC Genomic Workbench software 12.1 (Qiagen, Venlo, The Netherlands) was used. The main steps of the analysis included barcode and adapter trimming, quality trimming, short read ( $<15 \mathrm{nt})$ filtering, read mapping to the reference transcriptome (from Wachowiak et al. [20], containing 40,798 sequences), differential gene expression analysis and transcript annotation (using Blast2GO PRO plugin v. 1.12.11 for the CLC Genomic Workbench software (BioBam Bioinformatics, Valencia, Spain)). Quality trimming settings: quality trim enabled, quality limit 0.05 , ambiguous trim enabled, ambiguous limit 2, adapter trimming - automatic, discard short reads enabled, min. no. of nucleotides per read-15, max. no. of nucleotides per read-1000. RNA-Seq reference settings: one reference sequence per transcript, spike-in control handling disabled. RNA- 
Seq mapping settings: mismatch cost 2, insertion cost 3, deletion cost 3 , length fraction 0.8 , similarity fraction 0.8 , auto-detect paired distances enabled, strand specificity-both, max. no. of hits per reading-10. RNA-Seq expression settings: expression value-total counts, calculate an expression for genes without transcripts enabled. In the CLC Genomic Workbench software metadata tables are used to assign information about treatment type and repeat number to the libraries. This allows this software to take the fluctuations in gene expression among different replicates into account when calculating the fold change, FDR $p$ and other values. Annotation was done using the eukaryotic subset of the nonredundant protein sequences database (database name " $\mathrm{nr}$ v5" from NCBI). Nine of the reference sequences were found by BLAST analysis to probably be contaminants (of arthropod, fungal and bacterial origin) and were removed prior to further analysis, they are highlighted in red in Supplementary Table S2. Three biological replicates were used for the inoculated samples, as recommended [24]. However, only two biological replicates of wounded samples were available as principal component analysis (using normalized log CPM (count per million) values as input) during quality control steps indicated a deviation in one of the libraries (wounded sample, library 25S). Two biological replicates were used for control samples. H. annosum transcriptome data [57] was used to identify the presence of $H$. annosum sequences in the control, wounded and inoculated libraries. For comparison of obtained results with transcriptome dynamics in response to methyl jasmonate treatment, the analysis settings were as reported previously [50]. For a description of DEGs in Section 3.5. of the discussion the primary resource used was the information about proteins with names matching to the Blast2GO-generated description from UniProt (https:/ / www.uniprot.org/).

\section{Conclusions}

Our results show that there are significant differences between the effects of inoculation with H. annosum and wounding on the transcriptome of Scots pine. The main differences are the higher expression of TFs and genes involved in the E3 protein ligase complex, as well as changes in expression of different receptor genes in inoculated samples compared to wounded samples. ROS homeostasis regulation, water transport regulation and drought stress damage prevention mechanisms are significant at this stage of H. annosum infection, as expression profiles of genes involved in these processes differ between inoculated and wounded samples. Concerning phytohormones, it is evident that one day post-inoculation, there is no clear main pathway regulating plant defense against inoculation. Results show that the cellular levels of several phytohormones (auxin, jasmonic acid, gibberellin and others) are regulated in response to the treatments. The low level of similarity between the response to MeJa treatment and wounding/inoculation strongly suggests that the MeJa pathway is not the main pathway regulating plant defense in this study. Several genes encoding ABA-responsive proteins show expression differences comparing inoculation and wounding treatments and are probably involved in water transport. However, the regulation of aquaporins is varied and the extent to which $\mathrm{ABA}$ is important in this process in inoculated samples should be further studied. This study revealed inoculation specific responses, which can be further explored. One of the most promising area for additional research is the regulation of WRKY transcription factor genes. This initial research provides the basis for further studies, examining the diversity of responses in a range of Scots pine germplasm, identifying potential sources of resistance to $H$. annosum, which can be incorporated into the Scots pine breeding program.

Supplementary Materials: Supplementary materials can be found at https://www.mdpi.com/1422 $-0067 / 22 / 4 / 1505 / s 1$.

Author Contributions: Conceptualization, V.Š. and D.R.; methodology, V.Š.; software, V.Š.; validation, V.Š.; formal analysis, V.Š.; investigation, V.Š.; resources, V.Š.; data curation, V.Šs.; writingoriginal draft preparation, V.Š. and D.R.; writing—review and editing, V.Š. and D.R.; visualization, 
V.Š.; supervision, D.R.; project administration, D.R.; funding acquisition, V.Š. and D.R. All authors have read and agreed to the published version of the manuscript.

Funding: This research was funded by Latvian Council of Science, grant number 284/2012 "Investigation of molecular defense mechanisms in Scots pine (Pinus sylvestris L.)" and European Regional Development Fund Postdoctoral research aid, grant number 1.1.1.2/VIAA/3/19/510. The APC was funded by the Latvian State Forest Research Institute "Silava".

Data Availability Statement: Transcriptome sequences were deposited to the NCBI database, the BioProject ID containing the SRA data is PRJNA667902.

Acknowledgments: Latvian Biomedical Research and Study Center for their next-generation sequencing service supervised by D. Fridmanis and D. Gudrā.

Conflicts of Interest: The authors declare no conflict of interest. The funders had no role in the design of the study; in the collection, analyses, or interpretation of data; in the writing of the manuscript, or in the decision to publish the results.

$\begin{array}{ll}\text { Abbreviations } \\ \text { ABA } & \text { Abscisic acid } \\ \text { abs. } & \text { Absolute } \\ \text { DEG } & \text { Differentially expressed gene } \\ \text { ET } & \text { Ethylene } \\ \text { FC } & \text { Fold change } \\ \text { FDR } & \text { False discovery rate } \\ \text { JA } & \text { Jasmonic acid } \\ \text { MeJa } & \text { Methyl jasmonate } \\ \text { ROS } & \text { Reactive oxygen species } \\ \text { SA } & \text { Salicylic acid } \\ \text { TF } & \text { Transcription factor }\end{array}$

\section{References}

1. Asiegbu, F.O.; Adomas, A.; Stenlid, J. Conifer Root and Butt Rot Caused by Heterobasidion annosum (Fr.) Bref. s.l. Mol. Plant Pathol. 2005, 6, 395-409. [CrossRef] [PubMed]

2. Asiegbu, F.O.; Nahalkova, J.; Li, G. Pathogen-Inducible cDNAs from the Interaction of the Root Rot Fungus Heterobasidion annosum with Scots Pine (Pinus sylvestris L.). Plant Sci. 2005, 168, 365-372. [CrossRef]

3. Liu, J.J.; Sturrock, R.N.; Benton, R. Transcriptome Analysis of Pinus monticola Primary Needles by RNA-Seq Provides Novel Insight into Host Resistance to Cronartium ribicola. BMC Genom. 2013, 14, 1-16. [CrossRef] [PubMed]

4. Carrasco, A.; Wegrzyn, J.L.; Durán, R.; Fernández, M.; Donoso, A.; Rodriguez, V.; Neale, D.; Valenzuela, S. Expression Profiling in Pinus radiata Infected with Fusarium circinatum. Tree Genet. Genomes 2017, 13, 1-17. [CrossRef]

5. Visser, E.A.; Wegrzyn, J.L.; Myburg, A.A.; Naidoo, S. Defence Transcriptome Assembly and Pathogenesis Related Gene Family Analysis in Pinus tecunumanii (Low Elevation). BMC Genom. 2018, 19, 632. [CrossRef]

6. Adomas, A.; Heller, G.; Li, G.; Olson, Å.; Chu, T.M.; Osborne, J.; Craig, D.; Van Zyl, L.; Wolfinger, R.; Sederoff, R.; et al. Transcript Profiling of a Conifer Pathosystem: Response of Pinus sylvestris Root Tissues to Pathogen (Heterobasidion annosum) Invasion. Tree Physiol. 2007, 27, 1441-1458. [CrossRef]

7. Danielsson, M.; Lundén, K.; Elfstrand, M.; Hu, J.; Zhao, T.; Arnerup, J.; Ihrmark, K.; Swedjemark, G.; Borg-Karlson, A.K.; Stenlid, J. Chemical and Transcriptional Responses of Norway Spruce Genotypes with Different Susceptibility to Heterobasidion spp. Infection. BMC Plant Biol. 2011, 11, 154. [CrossRef]

8. Lundén, K.; Danielsson, M.; Durling, M.B.; Ihrmark, K.; Nemesio Gorriz, M.; Stenlid, J.; Asiegbu, F.O.; Elfstrand, M. Transcriptional Responses Associated with Virulence and Defence in the Interaction between Heterobasidion annosum s.s. and Norway Spruce. PLoS ONE 2015, 10, e0131182. [CrossRef]

9. Lind, M.; Källman, T.; Chen, J.; Ma, X.-F.; Bousquet, J.; Morgante, M.; Zaina, G.; Karlsson, B.; Elfstrand, M.; Lascoux, M.; et al. A Picea abies Linkage Map Based on SNP Markers Identifies QTLs for Four Aspects of Resistance to Heterobasidion parviporum Infection. PLoS ONE 2014, 9, e101049. [CrossRef]

10. Nagy, N.E.; Fossdal, C.G.; Dalen, L.S.; Lonneborg, A.; Heldal, I.; Johnsen, O. Effects of Rhizoctonia Infection and Drought on Peroxidase and Chitinase Activity in Norway Spruce (Picea abies). Physiol. Plant. 2004, 120, 465-473. [CrossRef]

11. Smith, J.A.; Blanchette, R.A.; Burnes, T.A.; Jacobs, J.J.; Higgins, L.A.; Witthuhn, B.A.; David, A.J.; Gillman, J.H. Proteomic Comparison of Needles from Blister Rust-Resistant and Susceptible Pinus strobus Seedlings Reveals Upregulation of Putative Disease Resistance Proteins. Mol. Plant Microbe Interact. 2006, 19, 150-160. [CrossRef] [PubMed] 
12. Verne, S.; Jaquish, B.; White, R.; Ritland, C.; Ritland, K. Global Transcriptome Analysis of Constitutive Resistance to the White Pine Weevil in Spruce. Genome Biol. Evol. 2011, 3, 851-867. [CrossRef] [PubMed]

13. Liu, J.J.; Williams, H.; Li, X.R.; Schoettle, A.W.; Sniezko, R.A.; Murray, M.; Zamany, A.; Roke, G.; Chen, H. Profiling Methyl Jasmonate-Responsive Transcriptome for Understanding Induced Systemic Resistance in Whitebark Pine (Pinus albicaulis). Plant Mol. Biol. 2017, 95, 359-374. [CrossRef] [PubMed]

14. Wang, L.; Li, Q.; Liu, Z.; Surendra, A.; Pan, Y.; Li, Y.; Zaharia, L.I.; Ouellet, T.; Fobert, P.R. Integrated Transcriptome and Hormone Profiling Highlight the Role of Multiple Phytohormone Pathways in Wheat Resistance against Fusarium Head Blight. PLoS ONE 2018, 13, e0207036. [CrossRef] [PubMed]

15. Qi, P.F.; Jiang, Y.F.; Guo, Z.R.; Chen, Q.; Ouellet, T.; Zong, L.J.; Wei, Z.Z.; Wang, Y.; Zhang, Y.Z.; Xu, B.J.; et al. Transcriptional reference Map of Hormone Responses in Wheat Spikes. BMC Genom. 2019, 20, 390. [CrossRef] [PubMed]

16. Nystedt, B.; Street, N.R.; Wetterbom, A.; Zuccolo, A.; Lin, Y.-C.; Scofield, D.G.; Vezzi, F.; Delhomme, N.; Giacomello, S.; Alexeyenko, A.; et al. The Norway Spruce Genome Sequence and Conifer Genome Evolution. Nature 2013, 497, 579-584. [CrossRef]

17. Zimin, A.V.; Stevens, K.A.; Crepeau, M.W.; Puiu, D.; Wegrzyn, J.L.; Yorke, J.A.; Langley, C.H.; Neale, D.B.; Salzberg, S.L. An Improved Assembly of the Loblolly Pine mega-Genome Using Long-Read Single-Molecule Sequencing. GigaScience 2017, 6, 1-4.

18. Lorenz, W.W.; Ayyampalayam, S.; Bordeaux, J.M.; Howe, G.T.; Jermstad, K.D.; Neale, D.B.; Rogers, D.L.; Dean, J.F.D. Conifer DBMagic: A Database Housing Multiple De Novo Transcriptome Assemblies for 12 Diverse Conifer Species. Tree Genet. Genomes 2012, 8, 1477-1485. [CrossRef]

19. Visser, E.A.; Wegrzyn, J.L.; Steenkmap, E.T.; Myburg, A.A.; Naidoo, S. Combined De Novo and Genome Guided Assembly and Annotation of the Pinus patula Juvenile Shoot Transcriptome. BMC Genom. 2015, 16, 1057. [CrossRef]

20. Wachowiak, W.; Trivedi, U.; Perry, A.; Cavers, S. Comparative Transcriptomics of a Complex of Four European Pine Species. BMC Genom. 2015, 16, 234. [CrossRef]

21. Mgbeahuruike, A.C.; Kohler, A.; Asiegbu, F.O. Expression Analysis of the Impact of Culture Filtrates from the Biocontrol Agent, Phlebiopsis gigantea on the Conifer Pathogen, Heterobasidion annosum s.s. Transcriptome. Microb. Ecol. 2013, 66, 669-681. [CrossRef] [PubMed]

22. Choi, J.; Lee, G.W.; Kim, K.T.; Jeon, J.; Détry, N.; Kuo, H.C.; Sun, H.; Asiegbu, F.O.; Lee, Y.H. Comparative Analysis of Genome Sequences of the Conifer Tree Pathogen, Heterobasidion annosum s.s. Genom. Data 2017, 14, 106-113. [CrossRef] [PubMed]

23. Liu, Y.; Zhou, J.; White, K.P. RNA-seq Differential Expression Studies: More Sequence or More Replication? Bioinformatics 2014, 30, 301-304. [CrossRef]

24. Conesa, A.; Madrigal, P.; Tarazona, S.; Gomez-Cabrero, D.; Cervera, A.; McPherson, A.; Szcześniak, M.W.; Gaffney, D.J.; Elo, L.L.; Zhang, X.; et al. A Survey of Best Practices for RNA-seq Data Analysis. Genome Biol. 2016, 17, 1-19. [CrossRef] [PubMed]

25. Cosgrove, D.J. Plant Expansins: Diversity and Interactions with Plant Cell Walls. Curr. Opin. Plant Biol. 2015, $25,162-172$. [CrossRef] [PubMed]

26. Li, L.; Hou, X.; Tsuge, T.; Ding, M.; Aoyama, T.; Oka, A.; Gu, H.; Zhao, Y.; Qu, L.J. The Possible Action Mechanisms of Indole-3-acetic Acid Methyl Ester in Arabidopsis. Plant Cell Rep. 2008, 27, 575-584. [CrossRef]

27. Hamilton, A.J.; Lycett, G.W.; Grierson, D. Antisense Gene That Inhibits Synthesis of the Hormone Ethylene in Transgenic Plants. Nature 1990, 346, 284-287. [CrossRef]

28. Schaller, F.; Hennig, P.; Weiler, E.W. 12-oxophytodienoate-10,11-reductase: Occurrence of Two Isoenzymes of Different Specificity against Stereoisomers of 12-oxophytodienoic Acid. Plant Physiol. 1998, 118, 1345-1351. [CrossRef]

29. Zhang, K.; Halitschke, R.; Yin, C.; Liu, C.J.; Gan, S.S. Salicylic Acid 3-hydroxylase Regulates Arabidopsis Leaf Longevity by Mediating Salicylic Acid Catabolism. Proc. Natl. Acad. Sci. USA 2013, 110, 14807-14812. [CrossRef]

30. Qiu, X.M.; Sun, Y.Y.; Ye, X.Y.; Li, Z.G. Signaling Role of Glutamate in Plants. Front. Plant Sci. 2020, 10, 1743. [CrossRef]

31. Schneider, K.; Kienow, L.; Schmelzer, E.; Colby, T.; Bartsch, M.; Miersch, O.; Wasternack, C.; Kombrink, E.; Stuible, H.P. A New Type of Peroxisomal Acyl-Coenzyme a Synthetase from Arabidopsis thaliana Has the Catalytic Capacity to Activate Biosynthetic Precursors of Jasmonic Acid. J. Biol. Chem. 2005, 280, 13962-13972. [CrossRef] [PubMed]

32. Yamaguchi, Y.; Nakamura, T.; Kusano, T.; Sano, H. Three Arabidopsis Genes Encoding Proteins with Differential Activities for Cysteine Synthase and $\beta$-cyanoalanine Synthase. Plant Cell Physiol. 2000, 41, 465-476. [CrossRef] [PubMed]

33. Romero, L.C.; Aroca, M.Á.; Laureano-Marín, A.M.; Moreno, I.; García, I.; Gotor, C. Cysteine and Cysteine-Related Signaling Pathways in Arabidopsis thaliana. Mol. Plant 2014, 7, 264-276. [CrossRef] [PubMed]

34. Hoo, S.C.; Howe, G.A. A Critical Role for the TIFY Motif in Repression of Jasmonate Signaling by a Stabilized Splice Variant of the JASMONATE ZIM-Domain Protein JAZ10 in Arabidopsis. Plant Cell 2009, 21, 131-145. [CrossRef]

35. Zik, M.; Arazi, T.; Snedden, W.A.; Fromm, H. Two Isoforms of Glutamate Decarboxylase in Arabidopsis Are Regulated by Calcium/Calmodulin and Differ in Organ Distribution. Plant Mol. Biol. 1998, 37, 967-975. [CrossRef]

36. Ramos-Ruiz, R.; Martinez, F.; Knauf-Beiter, G. The Effects of GABA in Plants. Cogent Food Agric. 2019, 5, 1670553. [CrossRef]

37. Jacob, H.J.; Bopp, M. Peroxidase Catalysed IAA Catabolism as One Part of Auxin Regulation in Funaria hygrometrica. J. Plant Physiol. 1990, 137, 88-94. [CrossRef]

38. Huang, J.; Gu, M.; Lai, Z.; Fan, B.; Shi, K.; Zhou, Y.H.; Yu, J.Q.; Chen, Z. Functional Analysis of the Arabidopsis PAL Gene Family in Plant Growth, Development, and Response to Environmental Stress. Plant Physiol. 2010, 153, 1526-1538. [CrossRef]

39. Fromm, H. GABA Signaling in Plants: Targeting the Missing Pieces of the Puzzle. J. Exp. Bot. 2020. [CrossRef] 
40. Bouché, N.; Fait, A.; Bouchez, D.; Møller, S.G.; Fromm, H. Mitochondrial Succinic-Semialdehyde Dehydrogenase of the $\gamma$ aminobutyrate Shunt Is Required to Restrict Levels of Reactive Oxygen Intermediates in Plants. Proc. Natl. Acad. Sci. USA 2003, 100, 6843-6848. [CrossRef]

41. Arazi, T.; Baum, G.; Snedden, W.A.; Shelp, B.J.; Fromm, H. Molecular and Biochemical Analysis of Calmodulin Interactions with the Calmodulin-Binding Domain of Plant Glutamate Decarboxylase. Plant Physiol. 1995, 108, 551-561. [CrossRef] [PubMed]

42. Kakiuchi, S.; Yamazaki, R. Calcium Dependent Phosphodiesterase Activity and Its Activating Factor (PAF) from Brain. Studies on Cyclic 3',5'-nucleotide Phosphodiesterase (III). Biochem. Biophys. Res. Commun. 1970, 41, 1104-1110. [CrossRef]

43. Murray, S.L.; Ingle, R.A.; Petersen, L.N.; Denby, K.J. Basal Resistance against Pseudomonas syringae in Arabidopsis Involves WRKY53 and a Protein with Homology to a Nematode Resistance Protein. Mol. Plant Microbe Interact. 2007, 20, 1431-1438. [CrossRef] [PubMed]

44. Pasquali, G.; Goddijn, O.J.M.; de Waal, A.; Verpoorte, R.; Schilperoort, R.A.; Hoge, J.H.C.; Memelink, J. Coordinated Regulation of Two Indole Alkaloid Biosynthetic Genes from Catharanthus roseus by Auxin and Elicitors. Plant Mol. Biol. 1992, 18, 1121-1131. [CrossRef]

45. Menke, F.L.H.; Champion, A.; Kijne, J.W.; Memelink, J. A Novel Jasmonate- and Elicitor-Responsive Element in the Periwinkle Secondary Metabolite Biosynthetic Gene Str Interacts with a Jasmonate- and Elicitor-Inducible AP2-Domain Transcription Factor, ORCA2. EMBO J. 1999, 18, 4455-4463. [CrossRef]

46. Bhattacharjee, S.; Halane, M.K.; Kim, S.H.; Gassmann, W. Pathogen Effectors Target Arabidopsis EDS1 and Alter Its Interactions with Immune Regulators. Science 2011, 334, 1405-1408. [CrossRef]

47. Wagner, S.; Stuttmann, J.; Rietz, S.; Guerois, R.; Brunstein, E.; Bautor, J.; Niefind, K.; Parker, J.E. Structural Basis for Signaling by Exclusive EDS1 Heteromeric Complexes with SAG101 or PAD4 in Plant Innate Immunity. Cell Host Microbe 2013, 14, 619-630. [CrossRef]

48. O'Brien, J.A.; Daudi, A.; Butt, V.S.; Bolwell, G.P. Reactive Oxygen Species and Their Role in Plant Defence and Cell Wall Metabolism. Planta 2012, 236, 765-779. [CrossRef]

49. Afzal, Z.; Howton, T.C.; Sun, Y.; Mukhtar, M.S. The Roles of Aquaporins in Plant Stress Responses. J. Dev. Biol. 2016, 4, 9. [CrossRef]

50. Kānberga-Silina, K.; Rauda, E.; Škipars, V.; Vivian-Smith, A.; Yakovlev, I.; Krivmane, B.; Šnepste, I.; Runǵis, D. Transcriptomic Response to Methyl Jasmonate Treatment of Scots Pine (Pinus sylvestris) Seedlings. Environ. Exp. Biol. 2017, 15, 257-274. [CrossRef]

51. Arnerup, J.; Nemesio-Gorriz, M.; Lundén, K.; Asiegbu, F.O.; Stenlid, J.; Elfstrand, M. The Primary Module in Norway Spruce Defence Signalling against H. annosum s.l. Seems to Be Jasmonate-Mediated Signalling without Antagonism of Salicylate-Mediated Signalling. Planta 2013, 237, 1037-1045. [CrossRef] [PubMed]

52. Gupta, D.; Ip, T.; Summers, M.L.; Basu, C. 2-Methyl-3-buten-2-ol (MBO) Synthase Expression in Nostoc punctiforme Leads to over Production of Phytols. Bioengineered 2015, 6, 33-41. [CrossRef] [PubMed]

53. Melan, M.A.; Dong, X.; Endara, M.E.; Davis, K.R.; Ausubel, F.M.; Peterman, T.K. An Arabidopsis thaliana Lipoxygenase Gene Can Be Induced by Pathogens, Abscisic Acid, and Methyl Jasmonate. Plant Physiol. 1993, 101, 441-450. [CrossRef] [PubMed]

54. Schluttenhofer, C.; Pattanaik, S.; Patra, B.; Yuan, L. Analyses of Catharanthus roseus and Arabidopsis thaliana WRKY Transcription Factors Reveal Involvement in Jasmonate Signaling. BMC Genom. 2014, 15, 1-20. [CrossRef] [PubMed]

55. Jaber, E.; Xiao, C.; Asiegbu, F.O. Comparative Pathobiology of Heterobasidion annosum during Challenge on Pinus sylvestris and Arabidopsis roots: An Analysis of Defensin Gene Expression in Two Pathosystems. Planta 2014, 239, 717-733. [CrossRef]

56. Škipars, V.; Šnepste, I.; Krivmane, B.; Veinberga, I.; Rungis, D. A Method for Isolation of High-Quality Total RNA from Small Amounts of Woody Tissue of Scots Pine. Balt. For. 2014, 20, 230-237.

57. Olson, Å.; Aerts, A.; Asiegbu, F.; Belbahri, L.; Bouzid, O.; Broberg, A.; Canbäck, B.; Coutinho, P.M.; Cullen, D.; Dalman, K.; et al. Insight Into Trade-Off between Wood Decay and Parasitism from the Genome of a Fungal Forest Pathogen. New Phytol. 2012, 194, 1001-1013. [CrossRef] 